\begin{tabular}{l}
\hline S sciendo $\frac{\text { ECONOMIC THEMES (2018) 56(2): 203-220 }}{\text { DOI 10.2478/ethemes-2018-0012 }}$ \\
\hline
\end{tabular}

\title{
THE POSITION OF TOURIST ESCORTS IN SERBIA
}

\author{
Aleksandra Dragin \\ University of Novi Sad, Faculty of Sciences, \\ Department of Geography, Tourism and Hotel Management, Republic of Serbia \\ $凶$ sadragin@gmail.com \\ Aleksandra Lazarević \\ University of Novi Sad, Faculty of Sciences, \\ Department of Geography, Tourism and Hotel Management, Republic of Serbia \\ $\triangle$ aleksandra.lazarevic77@gmail.com

\section{Maja Mijatov} \\ University of Novi Sad, Faculty of Sciences, \\ Department of Geography, Tourism and Hotel Management, Republic of Serbia \\ \majamijatov@gmail.com \\ UDC \\ 338.48 \\ (497.11) \\ Original \\ scientific \\ paper

\begin{abstract}
This paper deals with the position of tourist escorts in Serbia, primarily in a domain of business ethics. Employees' behaviour is important aspect of gaining the business stability, which is reflecting the importance of business ethics for reaching the prosperity within specific organisation, together with the improvement of business performances reflected in the form of financial indicators. The main results of the research are related to attitudes of tourist escorts from Serbia regarding the business ethics in a scope of their work. Historical method, together with a field research (work of one co-author within the position of tourist escort) and a research in the form of interviews were used for data collecting procedure. Furthermore, descriptive and analytical-synthetic methods were used in data processing and during the interpretation of the gained results. Research results could be useful in practical terms to the whole tourism industry, especially to tourist agencies, tourist escorts and tourist guides.
\end{abstract}

Received:

10.04.2018

Accepted:

28.05.2018
Keywords: tourist escort, Serbia, tourism, business ethics.

JEL classification: D79, D91, J8, M14, Z32, Z39. 


\section{Introduction}

Extensive literature devoted to the research of business ethics (Donaldson, 2003; Elci et al., 2007; Elias, 2005; Hansen \& Smith, 2006; Laksmi, 2004; MacDougall et al., 2015; Miller, 2014; Robertson \& Athanassiou, 2009; Serwinek, 1992; Sims \& Keon, 1997; Stark, 1992; Trevino, 1992; Valentine \& Barnett, 2002; Warren, 2011) points to the fact that academic and business worldis increasingly accepting the importance of implementation of business ethics in the business. On the other hand, basic researches of ethics in tourism within Serbia were not published before this decade (Dragin et al., 2013; Mijatov et al., 2015; Mišković, 2012; Simat et al., 2012; Simat \& Dragin, 2012; Šuleić et al., 2014; Šuleić et al., 2015).

Rakas (2001) states that every profession in the society strives to establish the system of appropriate values within the group and to implement these values into the business, due to the fact that ethical norms of the business could affect the economic aspects of organisational performances. In the end of the last century, conducted researches pointed out that successful companies which neglected the ethical values and other ethical elements within their business, increased the overall value of the company for $120 \%$ during the period of ten years. On the other hand, those companies that implemented some kind of ethical elements also increased the overall value of the company, but implementation of ethical issues raised this value for even $600 \%$ in the same period (during the one decade). The similar growth is evidenced within the increase of the shares' values. Thus, companies that involved unethical acts throughout performing their business tasks increased the value of their shares for $110 \%$, while those companies that implemented the ethical issues in the business reached higher increase of shares for even $900 \%$, also during the one decade (Hawley, 1993).

Furthermore, there are numerous examples of companies that were damaged in financial terms on the basis of their unethical practices (such as Enron, Global Crossings, World Com). Unethical behaviour within these companies influenced a formation of dissatisfaction within their customers, but such a behaviour also caused negative financial outcomes for the investors and all shareholders of these companies. On the other hand, there are numerous companies that implemented the ethical behaviour into the business and reached a high profit (such as: Hershey Foods: four billion dollars per year; Waste Management Inc: nine billion dollars per year; Home Depot: 20 billion dollars per year) (Martin \& Cullen, 2006; McMurrian \& Matulich, 2006).

Thus, considering the possible effects of business behaviour on general business success, it is important to notice that employees are important investment of the company and one of the most important resources for gaining the business competitiveness together with overall business success including the financial (incomes, profit, share values) and non-financial business performances (such as ability to create the tourists' satisfaction) (Gupta \& Zeitham, 2006; Kraja, 2011). 
However, there is a connection between financial and non-financial performances, which is the reason why behaviour of employees (including their efforts focused on (un)ethical issues) might be considered as important cause of financial business stability throughout influencing the tourists' satisfaction, as part of tourism demand that is very differentiated and sophisticated nowadays (Allard et al., 2009; Gligorijević \& Novović, 2018).

Employees' behaviour in terms of the business ethics could be researched within the different countries and different sectors. Accordingly, there is a question related to implementation and establishment of the value system in Serbia within the profession of tourist escorts, considering the importance of tourist escort's role during the realisation of tourist arrangements. Štetić (2003) points out that the activities of tourist escorts should be considered as activities of special social significance, since tourism could be seen as a passport of the peace. However, the profession of tourist escorts in Serbia is defined by the Law on Tourism in 2009 (Official Gazette of the Republic of Serbia, No. 36/2009, 88/2010, 99/2011, $93 / 2012,84 / 2015$ ), after a break that lasted for 15 years, so it does not seem to be fully regulated since then. In respect to this fact, several authors pointed to an unfavourable position of tourist escorts in Serbia in certain circumstances (Ajanović, 2010; Rabotić, 2009; Prelić, 2012), wich is related to several following facts.

First of all, tourism escorting should be treated as a serious profession because it involves responsibility, competences (general and specialized knowledge, different combinations of skills), ethical principles and it also implies specific working conditions. The profession of tourist escorts requires certain predispositions, primarily represented in the form of good health condition and psychological stability. According to the Law on Tourism, the tourist escort is a person that follows a group of tourists and performs operational and technical tasks from the beginning of the journey, to specific destination and back (Law on Tourism of the Republic of Serbia, 2009). Thus, due to the nature of working tasks, the tourist escort is constantly in the motion and in the interaction with different people, which could result in various social situations and all together is pointing to the fact that business tasks of tourist escorts include moral, business and financial responsibility towards different stakeholders. Since the reintroduction of this profession into the Serbian legislation and until the last few years, psychological testing was not provided as part of the exam for gaining the licence of tourist escorts, so numerous candidates gained a licence without the official psychological testing. Thus, for example, during the first years (in 2011 and 2013), 318 out of 400 candidates passed the exam and obtained the license for performing the job of the tourist escort (Dedijer, 2014).

Another important fact is related to development of emittive tourism in Serbia which is higher in comparison with the development of receptive tourism. This difference in tourism development is convinient for tourist escorts, due to the fact 
that their employment is based precisely on emittive tourism. However, licensing of tourist escorts was not implemented for a long time period (one decade and a half), which resulted in reorientation of tourist guides' efforts on activities of tourist escorting, while this reorientation consequently reduced the scope of work and engagement of travel escorts. Also, the Law on Tourism of the Republic of Serbia (2009) defined that tourist guides could deal with the activities of tourist escorts, while tourist escorts could not deal with the activities of tourist guides. All together narrowed the opportunities for employment of tourist escorts and it caused the creation of competition.

Seasonal characteristic of the employment, without constant working engagement, represents the main problem of the profession of tourist escorts in Serbia. The main periods of extensive working employment of tourist escorts in Serbia are during the summer season (June-September), when they are engaged in transfers of tourists to summer resorts, as well as the period of school excursions (April-June). During the stated periods, wrong impression might be formed regarding the fact that there is not enough number of tourist escorts, which resulted in additional engagement of tourist guides in activities of tourist escorts. However, since the period of employment is relatively short, most of the tourist escorts are performing these activities as additional sources of incomes in a combination with some other job.

As tourist escorts are rarely permanently employed in tourist agencies, there is a problem of their social saturation, including the way of regulating their pension and health insurance. Therefore, many of them are forced to independently pay the contributions to private pension funds or insurance companies.

The role of human resources is constantly changing, faster than before, so organisation of their education and trainings is constantly faced with improvements and innovations that are in line with new requirements of specific professions. Therefore, constant improvements of knowledge and competences among the human resources represent a key for gaining the development and acquisition of competitive advantage for specific society, which is the main reason why developed countries focused their intentions and efforts to education and training system of human resources, while Serbia still does not direct adequate attention to their specialization and education, which is the reason why human resources of different professions in this country, including the profession of tourist escorts, are left to themselves (Rabotić, 2009).

Furthermore, there are examples of unfair competition among the licensed tourist escorts. Some of them are even ready to work below the standard price, for tariffs that are lower than usual, due to the lack of work engagements, while some of them are even accepting to be illegally engaged by the employer, without the legal payments of taxes and contributions for their health and pension insurance (Prelić, 2012). 
Furthermore, Lazarević (2014) emphasises that the absence of official professional association of tourist escorts hinders their business performances and negotiations within the tourist market of Serbia. Throughout the joint actions of tourist escorts and their joint cooperation and activities, it would be easier to gain their rights and to advance their profession, including the entire status of tourist escorts. Due to the fact that association of tourist escorts is still not established, the official register of tourist escorts in Serbia is also not represented and available to tourist agencies which could not, therefore, alleviate the engagement of tourist escorts. Even the Serbian National Association of Travel Agencies (YUTA) only has a list of the licensed tourist guides on its website. In respect to that, tourist agencies recently use the capabilities of social networks and they access to the groups whose members are licensed tourist guides and escorts in order to advertise their necessities for services of tourist guides/escorts.

In order to overcome some of the key problems that tourist escorts in Serbia are often faced with, it is necessary to take certain measures and make corrections in all segments that might influence the quality of tourist services and further development of tourism in Serbia. According to already persisted problems of the profession of tourist escorts in Serbia, this research is focused on researching their awareness on business ethics and their general position within the tourist market in the field of ethical business.

\section{Methodology}

In order to collect the most accurate data on the attitudes and representation of business ethics in work of tourist escorts in Serbia, this research was conducted in the form of the interviews that was carried out during the September of 2014 on the sample that obtained ten licensed tourist escorts from Serbia. During the interviews, respondents answered the 18 questions divided into the three groups related to: general data about the respondents, business ethics, as well as the attitudes of Serbian tourist escorts regarding the implementation of business ethics in their work.

Issues related to business ethics are formed in respect to the basic theoretical settings of this term, including the Ethical Code for Tourist Guides of Slovenia and the Code of Business Ethics of the members within the Association of Travel Agencies in Bosnia and Herzegovina (Simat, 2012), as examples of good practice from the region. The particular importance of this research is related to the fact that indicates the absence of official ethical code for tourist escorts, tourist guides or tourist agencies in Serbia.

As the research was anonymous, respondents were marked as Person 1, Person 2, Person 3...., Person 10. Their answers pointed to the key results related to the main problems defined in the beginning of the paper, related to the profession of tourist escorts and implementation of business ethics in their work engagement. 
In addition to descriptive answers provided for specific questions, the respondents also expressed their attitudes towards specific statements by using the five-degree Likert's scale: 1 - I do not agree at all, 2 - I mostly/rarely disagree, 3 - I am not sure, 4 - I mostly/often agree, 5 - I completely agree. Although the research was conducted during September, when tourist escorts have a lot of work (finishing the summer tourist season and the beginning of the school excursions), the respondents were still interested in contributing to the research.

\section{Research results}

The research obtained the sample of 10 licensed tourist escorts. Even nine out of 10 respondents are female (which is typical for the majority of job positions in tourism). Respondents are aged between 25 and 43 years, eight of them gained a faculty education degree (four-years and five-years studies), one respondent completed a college (two-years studies), while one respondent gained a high school degree. It could be seen that most of the respondents are highly educated and their education is mainly in the field of the tourism, which is significant and useful for adequate performance of business tasks among the tourist escorts. The respondents are mostly employed on seasonal or part-time basis, while only two respondents are permanent employees and the average length of working tenure among the interviewed tourist escorts is about four years. It could be noted that tourist escorts included in this research are mostly young persons, without long work experience, which was even expected, due to the fact that mandatory licensing of tourist escorts was reintroduced only few years ago after a long break.

Part of the questions related to issues of business ethics were aimed at determining the meanings of business ethics and ethical behaviour among the tourist escorts. These questions also focused on gaining the information related to implementation of business ethics throughout the preparation of candidates for taking the professional exam and gaining the licence of tourist escorts including the manners of getting acquainted to the principles of ethical business.

Eight out of ten respondents said that they did not have any education related to business ethics during their trainings and preparations for passing the exam. Individuals mostly rely on their personal moral values and they were usually left to be self-informed regarding the rights and obligations of tourist escorts, tourists and employers. Since tourism is characterised by a high frequency of people, which could cause a realisation of numerous contacts between them, it is necessary and almost imperative for tourist escorts, to be in constant interaction with tourists, providers of tourist services and local community within the destination and to dispose with the knowledge regarding the business ethics and ethical business behaviour. 
Seven out of ten respondents consider that possession of tourist escort license does not oblige them to ethical conduct in performing their business tasks, while only three respondents consider that the license is a document that obliges them to adhering to the ethical principles and norms in their work. Despite the fact that seven out of ten respondents gained their education in tourism, even six of them did not passed throughout the previous training on business ethics, while only one tourism expert gained some form of the training regarding the business ethics. These results are pointing to the fact that respondents were left to themselves during the preparation of professional exam, at least in terms of business ethics, which is certainly a lack of the professional exam for gaining the licence of the tourist escort.

Next question is related to the previous one and it refers to the manner that possession of the license, as a document issued by the state, could affect the ethical behaviour of tourist escorts. Half of the respondents with qualifications in the field of tourism agree that the license does not oblige them on ethical business behaviour in any other way than moral. Two respondents believe that ethical behaviour could be determinated only by individual personality and that the license could not influence it. Furthermore, two respondents agree with the fact that possession of the license obliges the ethical business behaviour of tourist escorts, while one respondent with education degree in the field of tourism considers that only implementation of sanctions for unethical behaviour prescribed by the law could oblige tourist escorts to work ethically. Also, the majority of respondents consider that state institutions should clearly define rights and obligations for all licence holders, including the penalties and sanctions in situations of avoiding the implementation of ethics within the operation of tourist escorts with the licence. Until now, neither one case of subtracting the license was recorded. The only form of sanctions, which is defined by the Law on Tourism of the Republic of Serbia, is amercement, if person that provides services of tourist escorting did not pass the professional exam for taking the licence, or if the licensed tourist escort does not have valid identity card or a badge that should be carried out in right prescribed manner (Law on Tourism of the Republic of Serbia, 2009).

Another question is whether the employer informed his tourist escorts regarding the standards of business ethics before their engagement and in which form are these information available to tourist escorts. Following findings are available on the basis of respondents' answers: seven tourist escorts indicated that only several domestic travel agencies they work(ed) for informed them about the ethical standards prescribed by the agency, two respondents said that neither one of tourist agencies informed them about the ethical standards, while only one respondent was informed about the ethical standards of the business within all agencies where this tourist escort was/is employed. Also, more than half of the respondents (seven of them) answered that ethical standards were represented to them in verbal form, while only three respondents said that agencies prescribed the 
ethical code of business conduct in written form. Based on these answers, it could be concluded that domestic travel agencies in Serbia do not practice to inform their (permanent or seasonal) employees regarding the ethical standards or codes of conduct. The reason of this situation might be reflected in a fact related to nonexistence of aforementioned codes, or their formal existence, due to the fact that their establishment and implementation are often ignored. Details regarding the respondents' attitudes related to business ethics in the scope of their work are represented in Table 1.

Table 1: Respondents' attitudes regarding the profession of tourist escorts in Serbia and implementation of business ethics among their job

\begin{tabular}{|c|c|c|c|c|c|}
\hline \multirow[b]{2}{*}{ Statements } & \multicolumn{5}{|c|}{ Relative frequency (number of respondents) } \\
\hline & $\begin{array}{c}\text { Do not } \\
\text { agree (1) }\end{array}$ & $\begin{array}{c}\text { Mostly/rarely } \\
\text { agree (2) }\end{array}$ & $\begin{array}{c}\text { Not sure } \\
\text { (3) }\end{array}$ & $\begin{array}{c}\text { Mostly/often } \\
\text { agree (4) }\end{array}$ & $\begin{array}{c}\text { Completely } \\
\text { agree (5) }\end{array}$ \\
\hline $\begin{array}{l}\text { Business behaviour, in } \\
\text { accordance with ethical } \\
\text { principles, is mandatory } \\
\text { among the tourist escorts } \\
\text { and it represents important } \\
\text { topic within this profession }\end{array}$ & 1 & 4 & 2 & 2 & 2 \\
\hline $\begin{array}{l}\text { Products and services are } \\
\text { often promoted as better } \\
\text { than they actually are, } \\
\text { which might cause } \\
\text { different problems for } \\
\text { tourist escorts }\end{array}$ & 7 & 3 & 2 & 4 & 1 \\
\hline $\begin{array}{c}\text { Tourist escorts might } \\
\text { experience humiliation } \\
\text { within the workplace by } \\
\text { their supervisors }\end{array}$ & 1 & 3 & 3 & 1 & 2 \\
\hline $\begin{array}{l}\text { Tourist escorts strive to be } \\
\text { professional and } \\
\text { responsible regardless of } \\
\text { whether they like or not the } \\
\text { person they contact with }\end{array}$ & 7 & 1 & 3 & 1 & 5 \\
\hline $\begin{array}{c}\text { Tourist escorts are often } \\
\text { faced with moral dilemmas } \\
\text { and situations that require } \\
\text { from them to act } \\
\text { unethically }\end{array}$ & 1 & 7 & 2 & 2 & 5 \\
\hline $\begin{array}{l}\text { Tourist escorts are forced } \\
\text { to represent excursions } \\
\text { better than they actually } \\
\text { are, in order to contribute } \\
\text { to profit of the agency }\end{array}$ & 1 & 1 & 1 & 4 & 3 \\
\hline $\begin{array}{l}\text { Tourist escorts must accept } \\
\text { and confirm decisions of } \\
\text { the agency, even if they } \\
\text { know they are wrong }\end{array}$ & 1 & 7 & 3 & 2 & 4 \\
\hline $\begin{array}{l}\text { It is a practice to transfer } \\
\text { the false information } \\
\text { regarding the competitors } \\
\text { in order to achieve a } \\
\text { business success of the } \\
\text { agency }\end{array}$ & 4 & 3 & 2 & 1 & 1 \\
\hline
\end{tabular}




\begin{tabular}{|c|c|c|c|c|c|}
\hline $\begin{array}{l}\text { The agency has expeditious } \\
\text { approach for solving the } \\
\text { problems of tourists }\end{array}$ & I & 1 & 2 & 1 & 6 \\
\hline $\begin{array}{l}\text { The main interest of tourist } \\
\text { escort is to realise the } \\
\text { profit for the agency and } \\
\text { the most important person } \\
\text { during the trip is tourist } \\
\text { escort himself }\end{array}$ & 2 & 3 & 3 & 1 & 2 \\
\hline $\begin{array}{l}\text { Tourist escort should not } \\
\text { favour or disrespect the } \\
\text { tourists (regarding the } \\
\text { differences on religious or } \\
\text { national basis, gender } \\
\text { structure, age, etc.) }\end{array}$ & 1 & 1 & 1 & 1 & 10 \\
\hline $\begin{array}{l}\text { Tourist escorts must } \\
\text { maintain strictly } \\
\text { professional relationship } \\
\text { with the tourists }\end{array}$ & I & 1 & 1 & 4 & 5 \\
\hline $\begin{array}{l}\text { It is important to avoid } \\
\text { emotional rapprochement } \\
\text { with individuals during the } \\
\text { journey, to avoid a } \\
\text { dissatisfaction within the } \\
\text { other members of the group }\end{array}$ & I & 1 & 1 & 2 & 6 \\
\hline $\begin{array}{l}\text { In order to hide the fact } \\
\text { that they made some } \\
\text { mistakes and to avoid the } \\
\text { tourists' dissatisfaction, } \\
\text { tourist escorts are } \\
\text { sometimes forced to lie }\end{array}$ & I & 2 & 1 & 4 & 3 \\
\hline $\begin{array}{l}\text { Tourist escorts should not } \\
\text { express their personal } \\
\text { opinions regarding the } \\
\text { tourist products/services, } \\
\text { they rather outline the } \\
\text { attitudes of the agency }\end{array}$ & I & 1 & 1 & 3 & 5 \\
\hline
\end{tabular}

Source: Data obtained throughout the research

One of the statements was regarding the fact that business behavior in accordance with the ethical principles is mandatory among the tourist escorts, as well as regarding the fact that business ethics represents a matter of great importance within the profession of tourist escorts. Almost half of the respondents replied that they mostly disagree with this statement, while two (out of ten respondents) stated that they were not sure regarding this issue (Table 1), which is a devastating result, considering the constant interaction of tourist escorts with tourists and business partners, as well as considering their important role during the journey.

It is not a rare situation for tourist escorts to experience humiliation within the workplace by their supervisors. One third of the respondents agree with this statement, while other respondents are not sure or they disagree with the abovementioned statement (Table 1). This attitude and behaviour of supervisors could greatly undermine interpersonal relations, which could also affect the quality 
of tourist escorts' services, while all together could be reflected on the quality of overall tourist outcome.

Next statement is related to tourist escorts' efforts focused on being polite and responsible regardless of whether they like or not the person they contact with. Two thirds of the respondents agree with this statement, while remaining third is not sure about this claim (Table 1). This finding shows that tourist escorts are aware of the importance of respecting the all individuals with whom they come into the contact while performing their job.

Tourist escorts' opinions regarding the moral dilemmas and situations that require from them to act unethically are generally divided. More than half of the interviewed tourist escorts experience such situations, while others are not sure on this issue (Table 1). This result could be explained by the fact that tourist escorts in Serbia are mostly young persons, with insufficient length of working tenure, so they still did not gained enough practice in their work.

Tourist escorts are often faced with situations of promoting and selling the products and services as better than they actually are, which could result in tourists' dissatisfaction. The first person that would be faced with their complaints is tourist escort. Five respondents agree with this statement, while remaining five are uncertain of this claim or they even disagree with it (Table 1). This finding is actually pointing to the fact that the tourist market is still insufficiently regulated in Serbia.

A positive attitude towards statement that tourist escorts often need to represent the facultative excursions as better than they actually are, in order to contribute to the increase of agencies' profit, is represented among the seven respondents, two respondents absolutely reject this claim, while one tourist escort is not sure about this statement (Table 1). This finding, where seven out of ten respondents agree with this statement, is pointing to the fact that false representation of tourist products and services became a practice and that it is often expected from tourist escorts to promote products and services as better than they actually are, in order to gain the short-term interest of specific agency. It should be emphasised that this attitude could create a counter-effect among the tourists in terms of their experience and the level of satisfaction with specific product or service.

Attitudes of tourist escorts related to the fact that they need to protect decisions of the agency, even in situations when they know that some of those decisions are not correct, are divided, given that six respondents agree with this fact, three of them are not sure about this claim, while one respondent is fully rejecting this statement (Table 1). Based on the gained answers, where more than half of the respondents agree with the stated claim, it could be concluded that employers encourage their tourist escorts to behave unethically, asking them to protect the employer within the business, even their mistakes. 
Results of conducted interviews pointed out that only one tourist escort agrees with the practice of providing the false information about the competitive agencies in order to achieve better business results, seven of them completely disagree with this fact, while two tourist escorts are not sure about this statement (Table 1). Results related to this statement are providing the knowledge regarding a dose of ethical awareness towards respecting the competitors, which is one of the important prerequisites for creating the health competition and successful business.

Seven interviewed tourist escorts agree with the fact that is pointing to immediate approach to resolving the tourists' complaints, while three respondents were not sure or they even disagree with this statement (Table 1). It remains to hope that these three respondents will understand the importance of rapid response to tourists' problems, since the main role of the tourist escort is solving the operational and technical problems and assistance during the journey.

All ten respondents agree that tourist escorts should not favour or humiliate the tourists (on religious or national basis, or according to their gender structure, age, etc.). These results are encouraging implementation of business ethics.

Almost all of interviewed tourist escorts agree with the fact that they must maintain a strictly professional relationship with tourists, while only one tourist escort did not agree with the stated claim (Table 1). An unprofessional attitude, too comfortable behaviour or uneven attention provided to tourists could negatively affect individuals, but also the rest of the group, which could create an inconvenient situation during the journey and even conflicts.

Two-thirds of the respondents pointed out that they are sometimes forced to lie to hide the fact that they made some mistakes or to avoid the tourists' dissatisfaction. Remaining third of the respondents mainly disagree with the aforementioned statement. Dissimulating the truth and giving the inaccurate information are considered as unethical forms of business behaviour and it is necessary to eliminate them from business relations.

Statement regarding the fact that tourist escorts should not express their personal opinions regarding the tourist product/service, but the views of the agency, is confirmed by eight respondents, one respondent is not sure, while one completely disagrees with this claim (Table 1). Therefore, it could be concluded that tourist escorts are supporting their agencies and supervisors even in situations when their behaviour is extremely unethical.

After expressing the level of their agreements/disagreements with the aforementioned statements, respondents were asked to describe some unpleasant situation, if they experienced it during their business engagement and to indicate who helped them in solving these problems and in which manner. Their answers are given in the following text. 
Person 1: "I was attacked verbally by a lady in a duty free shop because she thought that she would not have enough time for shopping, so she started with insulting and cursing to my exposure that we have to hurry up, due to the slowdowns at the border crossings. The drivers supported to me, confirming that the timetable must be followed, as it is done by the other members of the group, in opposite she could continue the journey within some other bus. Of course, she finished her shopping in five minutes."

Person 2: "The agency that hired me to follow the one school excursion consciously sent me to this excursion with insufficient number of tickets for entering in a museum, thinking that employees of the museum would not count the number of the children. But the tickets were distributed directly to the children by one employee who noticed that reported number of pupils is incompatible with the number identified on the field. Of course, the museum employee blamed me for this situation in front of the whole group. Fortunately, I had enough money to pay the tickets for the rest of the children."

Person 3: "The agency organised one-day excursion that was physically impossible to be realised in the period predicted by the schedule. I was almost 18 hours on the field, while the daily wage for this working time was too low."

Person 4: "There are numerous travellers who are striving to purchase the travel by the first or the last price, in the preseason and in the end of the current season. In respect to that, some passengers often pay only 50 euros for the entire arrangement, but they often complain on everything, starting from the mosquitoes in the bus, up to the grass on the beach that should be regulated and cleaned by the municipality, while the agency needs to inform the passengers regarding such a situation within the beach. Drivers provide their assistance in overcoming these complaints in most of the cases."

Person 5: "Transfer of one group of tourists throughout their returning from a holiday was organised by two buses, due to the fact that the group was too large. However, one lady objected to enter the bus in which she was distributed, because she did not travel with that bus upon arrival to the destination. Due to the fact that buses were almost identical, more precisely, they differed only by the colour, I explained to her that she would have the same seat as during the arrival, but she did not want to accept it. Furthermore, she was bitter and unpleasant and she did not want to get into the bus at all. Son of the owner of the agency was watching this situation on the side and when he saw that she gone too far, he approached and presented himself as the owner of the agency and he said that I was completely right about everything and he explained to her fairly that travel contract does not contain the clauses regarding the fact that the same bus must be engaged during departing and returning and that she could return home only if she gets into the bus in which she is distributed. After that, she immediately calmed down and entered the bus, without any additional comments or complaints." 
Person 6: "The beginning of the journey started with a delay because the bus was inoperative. However, the agency said that excursion needs to be realised, so I had to finish the excursion earlier, because I did not have a shuttle bus from the end of the tour to my house $(60 \mathrm{~km})$. I shortened the route within one destination and the group complained to the agency that they would not pay the last part of arrangement, because the excursion was not fully implemented in accordance with the contract. I left without the daily wage, which was the half of the last part of the whole amount of the payment that tourists refused to pay, while the agency paid the other half on unpaid part of the arrangement."

Person 7: "During the one excursion, we came into the museum, where the curator left the facility without waiting for the group, although we were announced and the tickets were paid. After several unsuccessful calls, conducted by the employees of the museum, impatience and dissatisfaction of the group increased, so I was forced to contact my supervisors from the agency. They, also, failed in contacting the curator, so I was forced to apologise to travellers and explain them that problem did not occur as a result of unprofessional work of the agency, but the museum, and that their money, paid for the entrance fees, would be returned to them."

Person 8: "I had an inconvenience with the driver during the one trip. Throughout the ride, the back door of the bus suddenly opened. As I walked throughout the bus to check if everything is fine with the travellers, I immediately noticed what happened and suggested that to the driver. He tried to close the door automatically, but as he failed, he stopped the bus and immediately began to yell at me in front of the whole group of the passengers, blaming me for not controlling what is happening in the bus and saying that one of the passengers curiously pressed the button for the case of the danger to open the door. However, I saw what really happened, the actual cause of stated situation was in a fact that door of the bus was out of order. But he blamed me, in order to protect himself. I remained calm and without the answer to this provocation, so we continued our journey without any problems, but I complained to the agency regarding this event and driver's unprofessionalism."

Person 9: "In order to realise one excursion, the agency engaged two buses which turned out as inoperative and unable for transportation of the children, after required checkout of the police before departing. Everyone was dissatisfied starting from the school director, over the teacher, up to the parents. I was on the first front for listening their complaints, due to the fact that I was the only representative of the agency at the moment. There were insults, but also the threats from the parents. It was extremely unpleasant situation, while I was completely powerless to do something alone. I called the head of the agency and he told me that he would do his best to provide operative buses in the shortest possible time. However, the school director decided to cancel the excursion, due to the fact that parents were very angry." 
Person 10: "On one occasion, I was escorting the group of tourists during their returning from a holiday in Greece and I was responsible for the passengers distributed into the two buses. In that period, visas for tourists from our country were still represented, so representative of the agency, employed within the destination in Greece, packed the passports and group visas of the passengers, in order to help me, but he switched the documents by a mistake. When we arrived at the border crossing, the first custom officer did not pay the attention to the fact that the list of the passengers from the group visa did not matched with the passports he stamped, so he passed that bus, while the other custom officer was more careful during the inspection and he noticed this error and did not allow the bus to pass. In the meantime, the first bus left with the group visa and made a break in front of a duty free shop, so I literally had to run for a bus, in order to replace visas. Luckily the passengers did not complain, because I reacted quickly and I managed to replace visas, so the passport control was ended as soon as possible and the passengers did not have to wait for a long time."

\section{Conclusion}

On the basis of this research, the authors wanted to point out the current position of tourist escorts in Serbia. After representing the already identified problems in the introduction related to the aforementioned profession, attention was focused on insufficiently affirmed business ethics issues in domain of the profession of tourist escorts in Serbia. Consideration of business ethics is important aspect of gaining the business stability, which was one of the main reasons for researching the business behaviour of tourist escorts in terms of ethics, together with its influence on general business performances. Findings related to the fact that tourist escorts from Serbia mainly rely on personal assessments related to (un)appropriate acts in different situations is supporting the previously established attitudes towards business ethics.

It is considered that such an issue is a result of the fact that there is not enough attention focused on this topic during the training for licensing of tourist escorts. Also, the majority of respondents consider that state bodies, as licensors, should clearly define the rights and obligations related to the possession of the license, as well as penalties and sanctions in the case of non-compliance or violation of rights and obligations related to the application of ethics in the work of licensed tourist escorts. Findings suggest that domestic travel agencies often do not have the practice to inform their employees, or seasonally engaged human resources, regarding the guidelines on ethical standards or codes of business conduct. On contrary, tourist escorts believe that travel agencies they work for often expect from them to act unethically in order to achieve short-term interests of the company. 
Considering that only a few competitions for licensing of tourist escorts have been announced so far, one can hope that more attention will be paid towards improving this profession in the future, together with more intensive implementation of business ethics in the profession of tourist escorts. Thus, on the basis of the research results, it could be said that ethics plays an important role in shaping the business results of travel agencies, including their financial performances, so business behaviour of tourist escorts needs to be considered in serious and responsible manner.

\section{Acknowledgement}

Represented research is part of the project funded by the Ministry of Education, Science and Technological Development of Republic of Serbia (OI 176020), as well as a part of the research conducted for the purpose of writing the master thesis of one of the co-authors (Aleksandra Lazarević and her mentor PhD Aleksandra Dragin).

\section{References}

Ajanović, E. (2010). Principi funkcionisanja i kvalitet turističkog vođenja (dimplomski rad). Beograd: Univerzitet Singidunum.

'Allard, T., Babin, B. J. and Chebat, J. C. (2009). When income matters: Customers evaluation of shopping malls' hedonic and utilitarian orientations. Journal of Retailing and Consumer Services, 16 (1), pp. 40-49.

Dedijer, I. (2014). Intervju o licenciranju turističkih pratilaca u Srbiji. Beograd: Ministarstvo trgovine, turizma i telekomunikacije Republike Srbije.

Donaldson, T. (2003). Taking ethics seriously - A mission now more possible. The Academy of Management Review, 28, pp. 363-366.

Dragin, A., Jovanović, T. and Besermenji, S. (2013). Ethical climate in hospitality facilities in Serbia. The Proceedings of the Conference 15th Contemporary Trends in Tourism and Hospitality - CTTH 2013. University of Novi Sad: Faculty of Sciences, Department of Geography, Tourism and Hotel Management.

Elci, M., Kitapci, H. and Erturk, A. (2007). Effects of quality culture and corporate ethical value on employee work attitudes and job performance in Turkey: An integrative approach. Total Quality Management, 18 (3), pp. 285-302.

Elias, R. Z. (2005). The effect of corporate ethics values on accountants' perception of social responsibility. Journal of Apllied Business Research, 21 (4), pp. 1-10.

Gligorijević, A. and Novović, M. (2018). The resource valorisation of authentic tourist offer of western Serbia. Economic Themes, 56 (1), pp. 105-125.

Gupta, S. and Zeitham, V. (2006). Customer metrics and their impact on financial performance. Marketing Science, 25 (6), pp. 718-739.

Hansen, F. and Smith, M. (2006). The ethics of business strategy. Handbook of Business Strategy, 7 (1), pp. 201-206.

Hawley, J. (1993). Reawakening the spirit in work: The power of dharmic management. Berrett-Koehler Publishers. 
Kraja, G. (2011). The importance of human resource management and performance in tourism. Proceedings of the Contemporary Trends in Tourism and Hospitality (Via Danube, the main Street of Europe). Novi Sad: Faculty of Sciences, Department of Geography, Tourism and Hotel Management.

Laksmi, R. A. (2004). The effect of quality culture and corporate ethics values on intention to leave and organizational commitment. International Journal of Engineering and Management Sciences, 5 (2), pp. 140-145.

Lazarević, A. (2014). Poslovna etika i turistički pratilac (master rad, mentor dr Dragin, A.). Univerzitet u Novom Sadu: Prirodno-matematički fakultet, Departman za geografiju, turizam i hotelijerstvo.

MacDougall, A. E., Bagdasarov, Z., Johnson, J. F. and Mumford, M.D. (2015). Managing workplace ethics: An extended conceptualization of ethical sensemaking and the facilitative role of human resources. Personnel and Human Resources Management, 33, pp. 121-189.

Martin, K.D. and Cullen, J.B. (2006). Continuities and extensions of ethical climate theory: A meta-analytic review. Journal of Business Ethics, 69 (2), pp. 175-194.

McMurrian, R.C. and Matulich, E. (2006). Building customer value and profitability with business ethics. Journal of Business \& Economics Research, 4 (11), pp. 11-18.

Mijatov, M., Dragin, A. and Jovanović, T. (2015). Ethical climate in hotels of Kopaonik. The Proceedings of the Conference 16th Contemporary Trends in Tourism and Hospitality - CTTH 2015. University of Novi Sad: Faculty of Sciences, Department of Geography, Tourism and Hotel Management.

Miller, R. A. (2014). Profiles and shadows in business ethics. Moral saints and moral exemplars. Ethical Issues in Organizations, 10, pp. 97-115.

Mišković, I. (2012). Ethics in providing tourism services by travel agents in Serbia. Turizam, 16 (1), pp. 20-28.

Prelić, M. (2012). Poslovna etika i turistički vodič (master rad, mentor dr Dragin, A.). Univerzitet u Novom Sadu: Prirodno-matematički fakultet, Departman za geografiju, turizam i hotelijerstvo.

Rabotić, B. (2009). Turističko vođenje u savremenom turizmu (doktorska disertacija). Beograd: Univerzitet Singidunum.

Rakas, S. (2001). Uvod u poslovnu etiku. Beograd: Megatrend Univerzitet primenjenih nauka.

Robertson, C. J. and Athanassiou, N. (2009). Exploring business ethics research in the context of international business. Management Research News, 32 (12), pp. 11301146.

Serwinek, P. (1992). Demographic and related differences in ethical views among small businesses. Journal of Business Ethics, 11, pp. 555-566.

Simat, K. (2012). Turističke agencije Novog Sada i poslovna etika (master rad, mentor $\mathrm{dr}$ Dragin, A.). Univerzitet u Novom Sadu: Prirodno-matematički fakultet, Departman za geografiju, turizam i hotelijerstvo.

Simat, K. and Dragin, A. (2012). Poslovna etika - element uspešnog poslovanja turističkih agencija. Zbornik radova Departmana za geografiju, turizam i hotelijerstvo, 41, pp. 297-309.

Simat, K., Dragin, A. and Dragićević, V. (2012). The institutionalization of business ethics of travel agencies in Serbia. Turizam, 16 (3), pp. 113-123.

Sims, R. and Keon, T. (1997). Ethical work climate as a factor in the development of person-organization fit. Journal of Business Ethics, 16, pp. 1095-1105. 
Stark, A. (1992). What's the matter with business ethics? Harvard Business Review, 71 (3), pp. 38-48.

Štetić, S. (2003). Vodička služba u turizmu. Beograd: Samostalno izdanje autora.

Šuleić, M., Dragin, A. and Dragićević, V. (2014). Business ethics of tour operators - The case study of TUI. Turizam, 18 (4), pp. 154-165.

Šuleić, M., Dragin, A. and Dragićević, V. (2015). The relationship of a foreign tour operator in Serbia towards tourists based on the example of TUI. Turizam, 19 (1), pp. 1-12.

Trevino, L. K. (1992). Moral reasoning and business ethics: Implications for research, education and management. Journal of BusinessEthics, 11, pp. 445-459.

Valentine, S. and Barnett, T. (2002). Ethics codes and sales professionals' perceptions of their organizations' ethical values. Journal of Business Ethics, 40 (3), pp. 191-200.

Warren, R. C. (2011). Are we making progress in international business ethics? Humanomics, 27 (3), pp. 212-224.

Law on Tourism of Republic of Serbia. Official Gazette of the Republic of Serbia, No. 36/2009, 88/2010, 99/2011, 93/2012, 84/2015.

\section{POLOŽAJ TURISTIČKIH PRATILACA U SRBIJI}

Rezime: Rad se bavi položajem turističkih pratilaca u Srbiji, pre svega $u$ domenu poslovne etike. Ponašanje zaposlenih predstavlja važan aspekt dostizanja poslovne stabilnosti, što ukazuje na značaj poslovne etike u istraživanju koja se tiču poboljšanja poslovnih performansi, kako finansijskih tako i nefinansijskih. Glavni rezultati istraživanja se odnose na stavove turističkih pratilaca iz Srbije o poslovnoj etici u delokrugu njihovog rada. Za prikupljanje podataka korišćene su istorijska metoda, terensko istraživanje (rad koautora na poziciji turističkog pratioca) i anketno istraživanje. Prilikom obrade podataka i interpretacije rezultata upotrebljene su deskriptivna metoda i analitičko-sintetička metoda. Rezultati istraživanja mogu pomoći turističkoj privredi, naročito turističkim agencijama, turističkim pratiocima i turističkim vodičima.

Ključne reči: turistički pratilac, Srbija, turizam, poslovna etika. 


\section{Authors' biographies}

Aleksandra Dragin is an Associate Professor at the Faculty of Sciences Department of Geography, Tourism and Hotel Management, University of Novi Sad. Her main fields of interest are the following: cultural dimensions and communication in tourism, demographic transitions and tourism development, different forms of tourism, business ethics and corporate social responsibility in tourism etc. She teaches the following courses: Culture and Communication in Tourism, Selective Forms in Tourism, Nautical tourism, Internet in Teaching Geography (undergraduate studies); Ethics and Tourism (master academic studies); The Impact of Demographic Trends on Tourism Development (Doctoral studies). She also has experience as a teacher in subjects: Tourism and Business Diplomacy as well as The Teaching Facilities and Resources for Teaching in Teaching Geography. She is an author or co-author of 133 publications in the field of tourism. She is a member of MENSA, a member of the Assembly of Matica Srpska, a member of the Commission for the adoption of standards in the field of tourism and related services ISO / TC 228, a member of the Working Group for statistical research within the National Council for Tourism RS etc.

Aleksandra Lazarevic gained the title of MSc in tourism at the Faculty of Sciences - Department of Geography, Tourism and Hotel Management (University of Novi Sad). After finishing master studies, she also gained the licence of tourist escort. During the performance of this profession, she conducted different researches regarding the business tasks and problems that tourist escorts are often faced with. She also included different aspects of business ethics in her researches, not only regarding the tourist escorts, but also regarding the overall aspects of human resources. Her main fields of interests are business ethics, human resources, business of travel agencies and business tasks of travel escorts.

Maja Mijatov is a $\mathrm{PhD}$ student and a research associate at the Faculty of Sciences - Department of Geography, Tourism and Hotel Management (University of Novi Sad). Her main fields of interest are the following: business ethics, ethical climate, corporate social responsibility, business performances, job satisfaction, organizational commitment, service orientation, human resources. She is involved in teaching courses on Entrepreneur and Tourism Economics since February 2018 at the Faculty of Sciences - Department of Geography, Tourism and Hotel Management (University of Novi Sad). She is an author and co-author of different papers presented throughout the conferences (in Serbia and abroad) and within different academic publications. During the studies, she gained the scholarships of the Ministry of Education, Science and Technological Development of the Republic of Serbia for the PhD studies, scholarship of the Fund for encouraging the promotion of talented students of University of Novi Sad and scholarship of the Fund for Young Talents of the Republic of Serbia. 